Tack F.M., Lapauw F., Verloo M.G., 1997. Determination and fractionation of sulphur in a contaminated dredged sediment. Talanta 44, 2185-2192.

The original publication is available at http://www.elsevier.com/

\title{
DETERMINATION AND FRACTIONATION OF SULPHUR IN A CONTAMINATED DREDGED SEDIMENT
}

\author{
F. M. TACK, F. LAPAUW AND M. G. VERLOO \\ Laboratory of Analytical Chemistry and Applied Ecochemistry, University of \\ Ghent, Coupure Links 653, 9000 Gent, Belgium \\ Additional keywords: sulphur compounds; oxidation/reduction; extraction
}

Summary-Conversion of sulphur compounds in reduced, contaminated sediments that are brought in upland conditions may largely affect the potential mobility of heavy metal contaminants. We applied selected methods for the determination of total sulphur and sulphur fractions in a contaminated sediment in the reduced state and after gradual drying and oxidation during one month.

Dry ashing, followed by ion chromatographic detection, was reliable for the determination of total sulphur. Good recoveries were obtained in both reference samples and spiked samples. Total sulphur was $14.5 \pm 0.6 \mathrm{~g} \mathrm{~kg}^{-1}$ relative to dry sediment.

Wet chemical methods that involve the determination of acid-volatile, $\mathrm{Zn}-\mathrm{HCl}$ reducible, chromium-reducible, acetone-soluble and HI-reducible sulphur were used to estimate specific sulphur forms. Results for acetone-soluble sulphur were to high and not consistent with results for other fractions. Major part of sulphur in the sediment $(90 \%)$ was inorganic. Sulphides were converted partially to sulphate and to intermediary oxidised sulphur compounds upon oxidation of the sediment. The results suggested that the intermediary oxidised sulphur pool in the reduced sediment $(2.5 \mathrm{~g}$ $\mathrm{kg}^{-1}$ ) mainly consisted of pyrite, that was not converted during drying and oxidation. No significant changes in organic sulphur were detected.

\section{INTRODUCTION}

Contaminated dredged materials that are disposed on the land may be subjected to oxidation. As a result, the mobility of contained metals may change. ${ }^{1,2,3}$ In that context, conversions of sulphur compounds may play an important role. Iron and metals are released when their sulphides are moved into oxidising environments where they are unstable. ${ }^{1}$ The oxidation of metal sulphides may also result in acidification in soils that are drained and aerated. ${ }^{4}$

Various sulphur compounds occur in soils and sediments. Inorganic sulphur forms include sulphates $\left(\mathrm{SO}_{4}^{2-}\right)$, elementary sulphur (S), metal sulphides (e.g. FeS) and pyrite $\left(\mathrm{FeS}_{2}\right)$. In between the sulphates (oxidation state VI) and the sulphides, several intermediary oxidised sulphur species can exist or be formed, e.g. bisulphide $\left(\mathrm{S}_{2}^{2-}\right.$, oxidation state $-\mathrm{I})$, polysulphide $\left(\mathrm{S}_{\mathrm{n}}^{2-},-\mathrm{II} / n\right)$, disulphuroxide $\left(\mathrm{S}_{2} \mathrm{O}(\mathrm{g}),+\mathrm{I}\right)$, sulphur monoxide $(\mathrm{SO}(\mathrm{g}),+\mathrm{II})$, thiosulphate $\left(\mathrm{S}_{2} \mathrm{O}_{3}^{2-},+\mathrm{II}\right)$, dithionite $\left(\mathrm{S}_{2} \mathrm{O}_{4}^{2-},+\mathrm{III}\right)$, 
sulphurdioxide $\left(\mathrm{SO}_{2}(\mathrm{~g}),+\mathrm{IV}\right)$, sulphite $\left(\mathrm{SO}_{3}^{2-},+\mathrm{IV}\right)$ and sulphur trioxide $\left(\mathrm{SO}_{3}(\mathrm{~g})\right.$, $+\mathrm{VI})^{5}$. Organic sulphur forms are generally divided into the ester sulphate group and the carbon-bonded sulphur compounds ${ }^{6,7,8}$. In well drained, well-aerated soils, most of the inorganic sulphur normally occurs as sulphate. Under anaerobic conditions, the main form of inorganic sulphur in soils and sediments is sulphide and often elemental S. ${ }^{7}$

Sulphur contents in soils generally are between 0.1 and $0.5 \mathrm{~g} \mathrm{~kg}^{-1}$. Polluted sediments may contain more than $5 \mathrm{~g} \mathrm{~kg}^{-1}$. Inorganic sulphur compounds tend to dominate in polluted sediments while organic sulphur compounds normally make up the largest fraction in unpolluted sediments. ${ }^{8,9}$

In determination of total sulphur in soils and sediments, the various sulphur forms are converted by oxidation, most often to sulphate. This is achieved by digestion with concentrated acids, ashing with $\mathrm{Ag}_{2} \mathrm{O}$ and $\mathrm{NaHCO}_{3},{ }^{10}$ oxidation with $\mathrm{NaOBr}^{7}$ or alkaline fusion. ${ }^{11}$ For the determination of sulphur in the extract, ion chromatography compared favourably with the methylene blue method. ${ }^{10,12}$ Indirect atomic absorption $^{13}$ and $\mathrm{ICP}^{14,15}$ may also be used to quantify sulphate in the extract. The use of X-ray fluorescence for determination of total sulphur in soils gave satisfactory results ${ }^{16,17}$. Elemental analysers are being developed to determine total sulphur in soils and sediments. Their advantage lies in simplicity, speed and convenience. They appear, however, unsatisfactory for research requiring accurate and precise determination of total sulphur in soils or sediments. ${ }^{7}, 18$

The classical procedures for the determination of reduced and intermediary oxidised sulphur compounds in soils and sediments involve their reduction to $\mathrm{H}_{2} \mathrm{~S}$ and trapping the evolved $\mathrm{H}_{2} \mathrm{~S}$ in $\mathrm{Zn}$-acetate solutions. Trapped sulphide is classically determined by colorimetry with methylene blue or by iodometric titration ${ }^{7}$. Instrumental techniques such as high resolution X-ray spectrometry ${ }^{17}$, reflectance analysis $^{19}$ or a combination of thermogravimetric techniques ${ }^{20}$ are being developed to directly determine specific sulphur compounds in the solid sample, but as yet are not largely applied in environmental sulphur analysis.

Accurate determination of the reduced forms of inorganic sulphur is difficult, partly because of the ease with which they can be oxidised on exposure to air, but mainly because of the limitations of current analytical methods. ${ }^{7}$ We applied wet chemical methods for the determination of acid-volatile sulphur (AVS), Zn-HClreducible sulphur $(\mathrm{Zn}-\mathrm{HCl} \mathrm{S})$, chromium-reducible sulphur $\left(\mathrm{Cr}^{2+}\right.$-reducible $\left.\mathrm{S}\right)$, acetone-soluble sulphur and hydroiodic-acid-reducible sulphur (HI-reducible $\mathrm{S}$ ) on a reduced, contaminated sediment, which was subjected to gradual drying and oxidation such as occurs upon land disposal. The analytical results allow to estimate resulting changes in sulphur compounds that may occur upon land disposal of contaminated dredged materials and are critically evaluated. This may contribute to a better understanding and interpretation of analytical results from sulphur compound analysis and to an improved understanding of the factors that govern the fate and behaviour of pollutants in contaminated dredged materials.

\section{EXPERIMENTAL}

\section{Sampling}

Sediment was sampled from the confined upland disposal site Geuzenhoek, situated on the left bank of the Gent-Terneuzen canal, Belgium. The canal crosses an 
industrial area (steel production, thermal power plant, chemical and food industry). The sediment was dredged and disposed one year before our sampling. It was characterised by a high carbonate content $(15.2 \%)$ and a $\mathrm{pH}\left(1: 5\right.$ in $\left.\mathrm{H}_{2} \mathrm{O}\right)$ of 8 , and was polluted with heavy metals and organics. ${ }^{21}$ It was strongly reduced $(-200 \mathrm{mV}$ versus the standard hydrogen electrode). Organic matter content was $9.5 \%$.

At the time of sampling, $20-50 \mathrm{~cm}$ of water covered the sediments. Sediment grab samples were taken in October 1992 and collected in 10-litre polyethylene containers. Care was taken to minimise the contact time with the air. The sediment was stored covered with canal water.

\section{Experiment}

To assess sulphur fractions affected by gradual drying and oxidation of this reduced sediment, an 8-cm layer of the sediment (dry matter content: 44\%) was brought in a rectangular container $(50 \mathrm{~cm}$ length, $30 \mathrm{~cm}$ width and $10 \mathrm{~cm}$ height) and kept in the air at an ambient temperature of $20-22^{\circ} \mathrm{C}$. No water was allowed to drain: removal of water occurred by evaporation only. Every two days, the sediment was stirred using a rinsed polyethylene tube, and 5-10 g were sampled in a plastic bag. The bag was purged with $\mathrm{N}_{2}$ and sealed, and the sediment was homogenised by kneading. After about two weeks, the sediment had dried to the extent (dry matter content: 60\%) that aggregates remained upon mixing. These were broken to a diameter size of at most 2 $\mathrm{cm}$.

Total sulphur and various sediment characteristics were determined at the start of the experiment. Calcium carbonate content, organic matter content and sulphur fractions were determined at the start and after 16 and 30 days. Acid-volatile sulphur, extractable sulphate and chromium-reducible sulphur were determined every two days.

\section{Chemical analysis}

Organic matter was estimated by ashing during three hours at $450^{\circ} \mathrm{C} .{ }^{22}$ Carbonate content was determined by back titrating an excess of $0.5 \mathrm{~mol} \mathrm{~L}^{-1} \mathrm{HCl}$ added to an amount of sample containing $1 \mathrm{~g}$ dry matter with $0.5 \mathrm{~mol} \mathrm{~L}^{-1} \mathrm{NaOH}^{23} \mathrm{The} \mathrm{pH}$ of the sediment was measured potentiometrically in a 1:5 solid:liquid suspension of the sediment in distilled water. Redox potentials were measured by inserting a platinum electrode and a saturated calomel electrode in the sediment paste and waiting for a stable reading. During the experiments, redox measurements were performed in a 1:5 solid:liquid suspension. The values obtained therefore are not actual redox potentials in the undisturbed sediment, but should be considered merely as relative indicators for the progress of oxidation.

\section{Sulphur determinations}

Total sulphur. Total sulphur was determined by dry ashing ${ }^{7}$ and sulphate detection using ion-chromatography ${ }^{24}$. Air dry sediment $(0.5 \mathrm{~g})$ was ashed with $2.5 \mathrm{~g} \mathrm{NaHCO}_{3}$ and $0.1 \mathrm{~g} \mathrm{Ag}_{2} \mathrm{O}$ during $3 \mathrm{hrs}$ at $550^{\circ} \mathrm{C}$. The ashed residue was boiled in $50 \mathrm{~mL}$ of carbonate/bicarbonate buffer $\left(2.6 \mathrm{mmol} \mathrm{L}{ }^{-1} \mathrm{Na}_{2} \mathrm{CO}_{3}+2.4 \mathrm{mmol} \mathrm{L}^{-1} \mathrm{NaHCO}_{3}\right)$ during 3 hours under reflux to extract sulphates, that were analysed in the filtrate by ionchromatography (Dionex 2000i/SP). Aqueous standard solutions of sulphate (5 and 10 $\mathrm{mg} \mathrm{L}^{-1}$ ), freshly prepared using reagent grade anhydrous sodium sulphate (UCB, Brussels), were used for calibration. 
Extractable sulphate. An amount of wet sediment, equivalent to approx. $0.5 \mathrm{~g}$ dry matter, was extracted in $50 \mathrm{~mL}$ carbonate/bicarbonate buffer $\left(2.6 \mathrm{mmol} \mathrm{L}{ }^{-1} \mathrm{Na}_{2} \mathrm{CO}_{3}+\right.$ $2.4 \mathrm{mmol} \mathrm{L}^{-1} \mathrm{NaHCO}_{3}$ ) in a $250 \mathrm{~mL}$ polyethylene centrifuge tube. The extracting solution was previously flushed with $\mathrm{N}_{2}$-gas. The centrifuge tube was sealed using laboratory film after flushing the head space with $\mathrm{N}_{2}$-gas. The suspension was mechanically shaken during $1 \mathrm{hr}^{25}$, centrifuged $(1500 \times \mathrm{g}$ during 20 minutes), and the supernatant liquid was analysed for sulphate by ion-chromatography.

Acid-volatile sulphur (AVS). The following procedures for quantifying sulphur fractions involved the reduction of sulphur to $\mathrm{H}_{2} \mathrm{~S}$ in an Johnson-Nishita apparatus ${ }^{26}$ and trapping the evolved $\mathrm{H}_{2} \mathrm{~S}$ in $\mathrm{Zn}$-acetate solutions. Acid-volatile, $\mathrm{Zn}-\mathrm{HCl}$ reducible, chromium-reducible, acetone-soluble and hydriodic-acid-reducible sulphur were determined as described by Wieder et $\mathrm{l}^{27}$

The sample (50 mg for the hydriodic-acid-reducible sulphur and $500 \mathrm{mg}$ for the other fractions) was added to the reaction flask and the system was purged with $\mathrm{N}_{2}$ at a bubbling rate in the $\mathrm{Zn}$-acetate traps of 1-2 bubbles per second for $10 \mathrm{~min}$ before the introduction of reagents.

AVS was determined by introducing $8 \mathrm{~mL}$ of $12 \mathrm{~mol} \mathrm{~L}^{-1} \mathrm{HCl}$ into the reaction flask. After 10 minutes, the suspension was brought to boiling and after 45 minutes the traps were removed and the sulphides titrated.

$\mathrm{Zn}$-HCl-reducible sulphur ( $\mathrm{Zn}-\mathrm{HCl} \mathrm{S}$ ). The procedure for the determination of $\mathrm{Zn}$ $\mathrm{HCl} \mathrm{S}$ was similar to that for AVS, except that $3 \mathrm{~g} \mathrm{Zn-metal} \mathrm{were} \mathrm{added} \mathrm{at} \mathrm{the} \mathrm{same}$ time as the acid. The material was boiled during 1 hour before removal of the traps and titration.

Chromium-reducible sulphur $\left(\mathrm{Cr}^{2+}\right.$-reducible $\left.\mathrm{S}\right) . \mathrm{Cr}^{2+}$-reducible $\mathrm{S}$ was determined by percolating a $1 \mathrm{~mol} \mathrm{~L}^{-1}$ solution of $\mathrm{CrCl}_{3} \cdot 6 \mathrm{H}_{2} \mathrm{O}$ in $0.5 \mathrm{~mol} \mathrm{~L}-1 \mathrm{HCl}$ through a Jones reductor column containing $\mathrm{Zn}$ amalgamated with $\mathrm{Hg}^{28} .16 \mathrm{~mL}$ of the reduced chromium solution were introduced into the reaction flask. After 10 minutes, heat was applied and the material treated as for $\mathrm{Zn}-\mathrm{HCl} \mathrm{S}$.

Acetone-soluble sulphur (acetone-soluble S). To determine acetone-soluble S, $0.5 \mathrm{~g}$ sediment were extracted during $16 \mathrm{hrs}$ with $20 \mathrm{~mL}$ of analytical grade acetone. The extraction flask was covered with Parafilm and placed on a horizontal shaker. The mixture was filtered and diluted to $25 \mathrm{~mL}$. The entire filtrate volume was introduced into the reaction flask and subjected to $\mathrm{Cr}^{2+}$-reduction as described above.

Hydriodic-acid-reducible sulphur (HI-reducible S). For the determination of HIreducible $\mathrm{S}$, a solution of 50\% hypophosphorous acid, $90 \%$ formic acid and $57 \%$ hydriodic acid in a proportion of 4:2:1 was prepared daily. 20 instead of $8 \mathrm{~mL}^{27}$ of that solution were brought in the reaction flasks. After 10 minutes, the suspension was heated to boil during 90 minutes.

Sulphide determination. After each of the extraction/distillation procedures, trapped sulphide was determined by iodometric titration. ${ }^{28}$ To the sequential wash bottles, $1 \mathrm{~mol} \mathrm{~L}^{-1} \mathrm{KIO}_{3}(8 \mathrm{~mL}$ to the first and $2 \mathrm{~mL}$ to the second bottle), $1.5 \mathrm{~g} \mathrm{KI}$ and $4 \mathrm{~mL}$ of concentrated $\mathrm{HCl}(37 \%)$ were added. The contents of the wash bottles were pooled in a $500 \mathrm{~mL}$ erlenmeyer and titrated with $0.01 \mathrm{~mol} \mathrm{~L}^{-1} \mathrm{Na}_{2} \mathrm{~S}_{2} \mathrm{O}_{3}$ using starch as an indicator. 


\section{RESULTS AND DISCUSSION}

\section{Total sulphur}

Analysis of total sulphur in reference plant material (spruce needles, CRM 101, Community Bureau of Reference, Commission of the European Communities, Brussels) agreed closely with the certified value (Table 1). For the sediment reference

Table 1 sample (CRM 277), we obtained higher results. Sulphur in the sediment reference material, however, was not certified, but indicative only. Reproducibility was excellent for the plant sample, but lower for the sediment samples. During ashing of sediments, as opposed to plant material, the large mineral matrix remaining may be responsible for the lower reproducibility. The higher variability in the analysis of the Geuzenhoek sample as compared to the reference sediment may result from additional random error related with the handling of wet sediments, i.e., increased possibility of sample heterogeneity and more uncertainty about the exact dry weight of the sample.

Spikes of inorganic (potassium sulphate) and organic sulphur (sulphanylamide) were recovered well. Sulphur contents determined were not significantly different from the expected value (t-test at the 0.05 level of significance), although the recovery of organic sulphur tended to be somewhat lower. Total sulphur analysis was therefore accurate and reproducible.

\section{Sulphur fractions}

Different sulphur fractions are thought to consist of specific sulphur forms. Sulphur contents in both the reduced and oxidised sediments were determined using various determination procedures (Table 2). The contents of specific sulphur forms may be estimated from the various sulphur determination procedures (Table 3).

Acid-volatile sulphur (AVS) is mostly sulphide S. ${ }^{27,29}$ In the reduced sediment, $70 \%$ of total sulphur was sulphide S. AVS was quantitatively converted during drying Table 3 and oxidation of the sediment (Table 2). The formation and accumulation of inorganic sulphur fractions is typical for polluted sediments and is related to a large influx of sulphur compounds, protons and metals. ${ }^{8}$

\section{$\mathrm{Zn}-\mathrm{HCl}$ sulphur}

It has been assumed that $\mathrm{Zn}-\mathrm{HCl} \mathrm{S}$ represents all inorganic sulphur except sulphate. ${ }^{30}$ Landers et $a l .{ }^{25}$ used the $\mathrm{Zn}-\mathrm{HCl}$ distillation procedure for the determination of inorganic non-sulphate sulphur but warned for incomplete recovery of pyrite when present in reduced soils or sediments. Wieder et al. ${ }^{27}$ found the procedure of questionable value because sulphur from $\mathrm{S}^{0}, \mathrm{FeS}_{2}$ and $\mathrm{SO}_{4}^{2-}$ was only partially recovered.

$\mathrm{Zn}-\mathrm{HCl} \mathrm{S}$ was significantly higher than AVS (Table 2). As extractable sulphates were negligible in the reduced sediment, the difference $\left(1.2 \mathrm{~g} \mathrm{~S}^{-1} \mathrm{~kg}\right.$ sediment $)$ must be attributed to the presence of $\mathrm{FeS}_{2}-\mathrm{S}$ or $\mathrm{S}^{0}-\mathrm{S}$.

In the oxidised sediment, the difference between $\mathrm{Zn}-\mathrm{HCl} \mathrm{S}$ and AVS was $2.3 \mathrm{~g}$ as compared to $1.2 \mathrm{~g}$ in the reduced sediment. This may result from sulphates in the oxidised sediments, that are partially determined as well. ${ }^{27}$

Wieder et $a l .{ }^{27}$ determined extraction/distillation efficiencies by analysing pure sulphur compounds with the different methods. They found that 15.5 to $24.0 \%$ of the added sulphate was determined as $\mathrm{Zn}-\mathrm{HCl} \mathrm{S}$. Assuming a recovery of $20 \%$, then 1.24 $\mathrm{g}$ of $\mathrm{Zn}-\mathrm{HCl} \mathrm{S}$ should have originated from sulphates present in the oxidised sediment 
(6.2 g). The remaining sulphur (1.06 g) agreed with the difference between $\mathrm{Zn}-\mathrm{HCl} \mathrm{S}$ and AVS in the reduced sediment (1.2 g). This may suggest either that the intermediary oxidised sulphur compounds were not affected in the dried, oxidised sediment, or that intermediary oxidised sulphur formed during oxidation was balanced by removal.

\section{Chromium-reducible sulphur}

Chromium-reducible sulphur represents all inorganic reduced and intermediary oxidised sulphur, i.e. iron monosulphides, pyrite $\left(\mathrm{FeS}_{2}\right)$ and elemental $\mathrm{S}^{27,31}$ The difference between $\mathrm{Cr}^{2+}$-reducible $\mathrm{S}$ and AVS was therefore listed as intermediary oxidised sulphur in Table 3.

Intermediary oxidised sulphur was estimated to be $2.5 \mathrm{~g} \mathrm{~kg}^{-1}$ in the reduced sediments. If this was $\mathrm{S}^{0}$, then $0.25 \mathrm{~g} \mathrm{~kg}^{-1}$ should be extracted in the $\mathrm{Zn}-\mathrm{HCl}$-fraction, assuming $10 \%$ recovery. ${ }^{27}$ If instead it was all $\mathrm{FeS}_{2}$, then $45 \%$ or $1.13 \mathrm{~g} \mathrm{~kg}^{-1}$ should be found in that fraction. The latter value agrees with the observed difference between $\mathrm{Zn}-\mathrm{HCl} \mathrm{S}$ and AVS $\left(1.2 \mathrm{~g} \mathrm{~kg}^{-1}\right)$ and therefore suggests that intermediary oxidised sulphur in the reduced sediment largely was $\mathrm{FeS}_{2}-\mathrm{S}$.

In the oxidised sediment, $1.06 \mathrm{~g}$ out of $2.3 \mathrm{~g} \mathrm{Zn}-\mathrm{HCl} \mathrm{S}$ was assumed to originate from intermediary oxidised sulphur (see before). Applying the percent recovery values for $\mathrm{FeS}_{2}$ in the $\mathrm{Zn}-\mathrm{HCl}$ and $\mathrm{Cr}^{2+}$-reducible extractions determined by Wieder et al., ${ }^{27}$ one can estimate the recovery of this intermediary oxidised sulphur as $1.06 \div 46 \% \times$ $93 \%=2.14 \mathrm{~g} \mathrm{~S}$, assuming that it is all $\mathrm{FeS}_{2}-\mathrm{S}$. Otherwise, if this intermediary oxidised sulphur were $\mathrm{S}^{0}-\mathrm{S}, 1.06 \div 12 \% \times 94 \%=8.3 \mathrm{~g}$ sulphur should be extracted in the $\mathrm{Cr}^{2+}$ reducible fraction. The latter value is far in excess of the experimentally found $\mathrm{Cr}^{2+}$ reducible sulphur in the oxidised sediment $(5.5 \mathrm{~g})$, while the former value corresponds with the intermediary oxidised sulphur in the reduced sediment $\left(\mathrm{FeS}_{2}-\mathrm{S}\right)$. It is therefore suggested that $\mathrm{FeS}_{2}$ was not largely affected during drying and oxidation of the sediment. Other $\mathrm{Cr}^{2+}$-reducible $\mathrm{S}$ in the oxidised sediment may include $\mathrm{S}^{0}$ and perhaps $\mathrm{S}_{2} \mathrm{O}_{4}^{2-}$ and $\mathrm{S}_{2} \mathrm{O}_{3}^{2-}$, formed by oxidation of sulphide $\mathrm{S}$.

It is not likely that new $\mathrm{FeS}_{2}$ would have been formed during oxidation of the sediment. The formation of pyrite in nature generally is a very slow process, taking months, years, or decades as amorphous iron monosulphides $(\mathrm{FeS})$ react with elemental sulphur $\left(\mathrm{S}^{0}\right){ }^{32}$ It has been shown that pyrite may also form rapidly without iron monosulphides as intermediates, provided soluble sulphides are present and iron monosulphides are undersaturated. ${ }^{32}$ These conditions are not likely to have occurred in the sediment studied, as large amounts of FeS were present.

\section{Acetone-soluble sulphur}

The method to determine acetone-soluble $\mathrm{S}$ is believed to be specific for $\mathrm{S}^{0}{ }^{27} \mathrm{We}$ found it difficult to obtain reproducible results for acetone-soluble sulphur. Visual detection of the endpoint of the titration was hindered by the presence of a turbidity in the wash bottles. The reproducibility was much lower than for the other sulphur fractions and the results obtained, moreover, were inconsistent with the other fractions.

Acetone-soluble $\mathrm{S}\left(6.9 \mathrm{~g} \mathrm{~S} \mathrm{~kg}^{-1}\right.$ dry sediment) was much higher than intermediary oxidised sulphur, estimated as the difference between $\mathrm{Cr}^{2+}$-reducible $\mathrm{S}$ and AVS (2.3 $\mathrm{g} \mathrm{S} \mathrm{kg}^{-1}$ dry sediment). Moreover, the sum of AVS and acetone-soluble $\mathrm{S}$ was higher than the total sulphur. It is therefore not possible to obtain an estimate for elemental 
sulphur from acetone-soluble S. It could be concluded from these high values that intermediary oxidised sulphur largely consisted of elemental sulphur in this sediment, but this is in contradiction with the results obtained for $\mathrm{Zn}-\mathrm{HCl} \mathrm{S}$ and $\mathrm{Cr}^{2+}$-reducible $\mathrm{S}$, as illustrated before.

\section{HI-reducible sulphur}

HI-reduction is commonly used to measure organic ester sulphate $\mathrm{S}$, with the attendant assumption that the procedure liberates sulphur from all inorganic sulphur compounds as well. ${ }^{27}$ Ester sulphate $\mathrm{S}$ may thus be estimated by the difference between HI-reducible $\mathrm{S}$ and the sum of $\mathrm{Cr}^{2+}$-reducible $\mathrm{S}$ and sulphate $\mathrm{S}$. Carbonbonded sulphur is estimated as the difference between total $\mathrm{S}$, inorganic $\mathrm{S}$ and ester sulphate $\mathrm{S}$.

The estimation by difference was uncertain because of the large inorganic sulphur pool compared to organic sulphur in our sediment. For comparison, Wieder et al. ${ }^{27}$ estimated sulphur fractions in peat soils, containing approx. $0.9 \mathrm{~g}$ ester sulphate $\mathrm{S}$ and only $0.6 \mathrm{~g}$ inorganic $\mathrm{S} \mathrm{kg}^{-1}$ dry sediment.

\section{Changes in inorganic sulphur fractions with time}

Changes in inorganic sulphur fractions with time are shown in Figure 1. Sulphides steadily decreased to zero within 30 days. The decrease proceeded faster at day 16 and coincided with the sediment starting to form aggregates upon mixing. A better contact with the air was thus established, resulting in a faster drying and a faster increase in redox potential (Table 4).

The significant decrease in carbonate content shows that a substantial amount of acidity was produced upon oxidation of the sediment. The oxidation of metal sulphides is a major cause of acidification in soils that are drained and aerated. ${ }^{4}$ Because of the high carbonate content, the sediment was efficiently buffered, as illustrated by the $\mathrm{pH}$ values. Gambrell et al. ${ }^{33}$ reported on a carbonate free sediment for which the $\mathrm{pH}$ dropped from neutral (7.0) to strongly acidic (3.0) after stirring under air for 8 days.

\section{CONCLUSIONS}

The determination of total sulphur by dry ashing, followed by ion chromatographic detection of sulphate, was reliable. Application of a fractionation scheme allowed to estimate sulphur fractions, but because of the possibility of large relative errors, the estimation of minor fractions may be difficult. Our determination of $S^{0}$ by acetone extractable sulphur suffered from a low reproducibility. Values obtained were too high and were not consistent with results obtained for the other fractions.

Major part of sulphur in the sediment was inorganic. Sulphides were converted partially to sulphate and to intermediary oxidised sulphur compounds upon oxidation of the sediment. The results suggested that an intermediary oxidised sulphur pool in the reduced sediment consisted of pyrite, that was practically not affected within one month. No significant changes in organic sulphur were detected.

\section{REFERENCES}

1. J. N. Moore, W. H. Ficklin and C. Johns, Environ. Sci. Technol., 1988, 22, 432. 
2. R. P. Gambrell, J. Environ. Qual., 1994, 23, 883.

3. U. Förstner, Int. J. Environ. Anal. Chem., 1993, 51, 5.

4. S. Satawathananont, W. H. Jr. Patrick and P. A. Jr. Moore, Plant Soil, 1991, 133, 281-290.

5. L. W. Lindsay, Chemical equilibria in soils, John Wiley \& Sons, New York, 1979.

6. D. J. Casagrande, K. Siefert, C. Berschinski and N. Sutton, Geochim. Cosmochim. Act., 1977, 41, 161.

7. M. A. Tabatabai, Methods of soil analysis. Part 2. Chemical and microbiological properties, C.A. Black et al. (ed.), p. 501. ASA, Madison, Wisconsin, 2nd edition, 1982.

8. J. O. Nriagu and Y. K.Soon, Geochim. Cosmochim. Acta, 1985, 49, 823.

9. M. J. Mitchell, D. H. Landers, F. B. Brodowski, G. B. Lawrence and B. David, Water Air Soil Pollut., 1984, 21, 231.

10. M. A. Tabatabai, N. T. Basta and H. J. Pirela, Commun. Soil Sci. Plant Anal., 1988, 19, 1701

11. E. A. Stallings, L. M. Candelaria and E. S. Gladney, Anal. Chem., 1988, 60, 1246.

12. W. A. Dick and M. A. Tabatabai, Soil Sci. Soc. Am. J., 1979, 43, 899.

13. M. C. Du Toit and C. C. Du Preez, Commun. Soil Sci. Plant Anal., 1995, 26, 69.

14. M. W. Pritchard and J. Lee, Anal. Chim. Acta, 1984, 157, 313.

15. P. F. Vendrell, K. Frank and J. Denning, Commun. Soil Sci. Plant Anal., 1990, 21, 1695.

16. M. A. Tabatabai and J. M. Bremner, Soil Sci. Soc. Am. Proc., 1970, 34, 417.

17. Q. G. Wang, Z. H. Huang, Q. Zhang, Environ. Chem., 1992, 11, 55.

18. J. F. Artiola, Int. J. Environ. Anal. Chem., 1990, 41, 159.

19. J. I. Wilcox and R. D. del Delumyea, Anal. Letters, 1994, 27, 2805.

20. F. Paulic and M. Arnold, J. Thermal Analysis, 1993, 39, 1079.

21. F. M. Tack, O. W. J. J. Callewaert and M. G. Verloo, Environ. Pollut., 1996, 91, 199.

22. E. R. Rhodes, P. Y. Kamara and P. M. Sutton, Soil Sci. Soc. Am. J., 1981, 45, 1132.

23. L. E. Allison and C. D. Moodie, Methods of soil analysis. Part 2. Chemical and microbiological properties, C.A. Black et al. (ed.), p. 1379. ASA, Madison, Wisconsin, $2^{\text {nd }}$ edition, 1965.

24. J. W. M. Rudd, C. A. Kelly, A. Furutani, Limnology Oceanography, 1986, 31, 1281.

25. D. H. Landers, M. B. David, M. J. Mitchell, Intern. J. Environ. Anal. Chem., 1983, 14, 245. 
26. C. M. Johnson and H. Nishita, Anal. Chem, 1952, 24, 736.

27. R. K. Wieder, G. E. Lang and V. A. Granus, Limnol. Oceanogr., 1985, 30, 1109.

28. A. I. Vogel, Vogels's textbook of quantitative inorganic analysis. Longman, London, $5^{\text {th }}$ edition, 1989.

29. A. E. Giblin, G. E. Likens, D. White and R. W. Howarth, Limnol. Oceanogr., $1990, \mathbf{3 5}, 852$.

30. M. B. David, M. J. Mitchell and J. P. Nakas, Soil Sci. Soc. Am. J., 1982, 46, 847852.

31. R. W. Howarth and S. Merkel, Limnol. Oceanogr., 1984, 29, 598.

32. R. W. Howarth, Science, 1978, 203, 49.

33. R. P. Gambrell, R. D. DeLaune, W. H. Jr. Patrick, Plant life under oxygen deprivation, M. B. Jackson, D. D. Davies and H. Lambers (ed.), p. 101. SPB Academic Publishing, The Hague, The Netherlands, 1991. 
Table 1. Analysis of total sulphur in reference samples, the Geuzenhoek sediment and spiked sediment samples ( $\mathrm{g} \mathrm{kg}^{-1}$ dry sediment)

\begin{tabular}{lcc}
\hline & Determined & Reference value \\
\hline Spruce needles (CRM 101) & $1.67 \pm 0.05(n=10)$ & $1.70 \pm 0.10^{*}$ \\
Estuarine sediment (CRM 277) & $6.06 \pm 0.25(n=10)$ & $5.17 \pm 0.18^{ \pm}$ \\
\hline Addition & Determined & Expected \\
\hline Geuzenhoek & $14.5 \pm 0.6(n=15)$ & \\
$\mathrm{K}_{2} \mathrm{SO}_{4}$ & $21.2 \pm 0.2(n=5)$ & $21.3 \pm 0.6$ \\
Sulphanylamide & $19.3 \pm 0.3(n=5)$ & $19.9 \pm 0.6$ \\
\hline
\end{tabular}

*Certified value

${ }^{ \pm}$Indicative value 
Table 2. Determination of sulphur fractions ( $\mathrm{g} \mathrm{kg}^{-1}$ dry sediment $)$

\begin{tabular}{lcc}
\hline & Reduced sediment & Oxidised sediment $^{\#}$ \\
\hline Total S & $14.5 \pm 0.6^{*}$ & \\
AVS & $10.4 \pm 0.3^{ \pm}$ & 0.0 \\
Zn-HCl S & $11.6 \pm 0.2^{ \pm}$ & 2.3 \\
Cr $^{2+}$-reducible S & $12.9 \pm 0.2^{ \pm}$ & 5.5 \\
Acetone-soluble S & $6.9 \pm 1.2^{ \pm}$ & - \\
HI-reducible S & $13.9 \pm 0.1^{ \pm}$ & 14.1 \\
Extractable sulphate & $0.08 \pm 0.01^{ \pm}$ & 6.2 \\
\hline
\end{tabular}

${ }^{*} \mathrm{n}=15$

${ }^{ \pm} \mathrm{n}=3$

\#no replicate measurements performed. Estimates on reproducibility may be obtained from replicate determinations on the reduced sediment 
Table 3. Estimation of sulphur fractions ( $\mathrm{g} \mathrm{kg}^{-1}$ dry sediment)

\begin{tabular}{lcc}
\hline & Reduced sediment & Oxidised sediment \\
\hline Total S & $14.5 \pm 0.6$ & $14.5^{*}$ \\
Organic S & $1.5 \pm 2.5$ & 2.8 \\
Carbon-bonded S & $0.6 \pm 2.0$ & 0.2 \\
Ester sulphate S & $0.9 \pm 0.6$ & 2.6 \\
Inorganic S & $12.9 \pm 0.8$ & 11.7 \\
Sulphide & $10.4 \pm 0.3$ & 0.0 \\
Intermediary oxidised & $2.5 \pm 0.5$ & 5.5 \\
Sulphate & $0.08 \pm 0.01$ & 6.2 \\
\hline
\end{tabular}

*Estimated from the total content determined at the start of the experiment 
Table 4. Evolution in sediment characteristics during drying and oxidation of the sediment (DM: dry matter content; EC: specific electrical conductivity; ORP: oxidoreduction potential)

\begin{tabular}{lcrrrrc}
\hline Day & $\begin{array}{c}\mathrm{DM} \\
\%\end{array}$ & $\begin{array}{c}\mathrm{EC} \\
\mathrm{mS} \mathrm{cm}^{-1}\end{array}$ & $\mathrm{pH}$ & $\begin{array}{c}\mathrm{ORP} \\
\mathrm{mV}\end{array}$ & $\begin{array}{c}\mathrm{CaCO}_{3} \\
\%\end{array}$ & $\begin{array}{c}\text { OM } \\
\%\end{array}$ \\
\hline 0 & 44 & 0.45 & 8.9 & -200 & $14 \pm 1$ & $9.3 \pm 0.2$ \\
2 & 45 & 0.60 & 8.0 & -5 & & \\
4 & 47 & 0.82 & 8.0 & -5 & & \\
6 & 48 & 0.75 & 8.2 & 5 & & \\
8 & 50 & 0.80 & 8.1 & 10 & & \\
10 & 51 & 1.07 & 7.9 & 20 & & \\
12 & 54 & 1.13 & 7.9 & 30 & & \\
14 & 56 & 1.28 & 7.6 & 45 & & \\
16 & 59 & 1.43 & 7.6 & 45 & $12 \pm 2$ & $9.2 \pm 0.2$ \\
18 & 65 & 1.79 & 7.6 & 60 & & \\
20 & 69 & 2.01 & 7.5 & 100 & & \\
22 & 74 & 1.93 & 7.6 & 170 & & \\
24 & 85 & 1.92 & 7.7 & 280 & & \\
26 & 90 & 1.91 & 7.6 & 290 & & \\
28 & 92 & 1.92 & 7.6 & 280 & & \\
30 & 94 & 1.93 & 7.6 & 290 & $10 \pm 0.8$ & $9.2 \pm 0.2$ \\
\hline
\end{tabular}




\section{FIGURE CAPTIONS}

Figure 1. Sum of chromium-reducible sulphur and sulphate sulphur as a function of time. Sulphide forms were plotted as a fraction of chromium-reducible sulphur. 


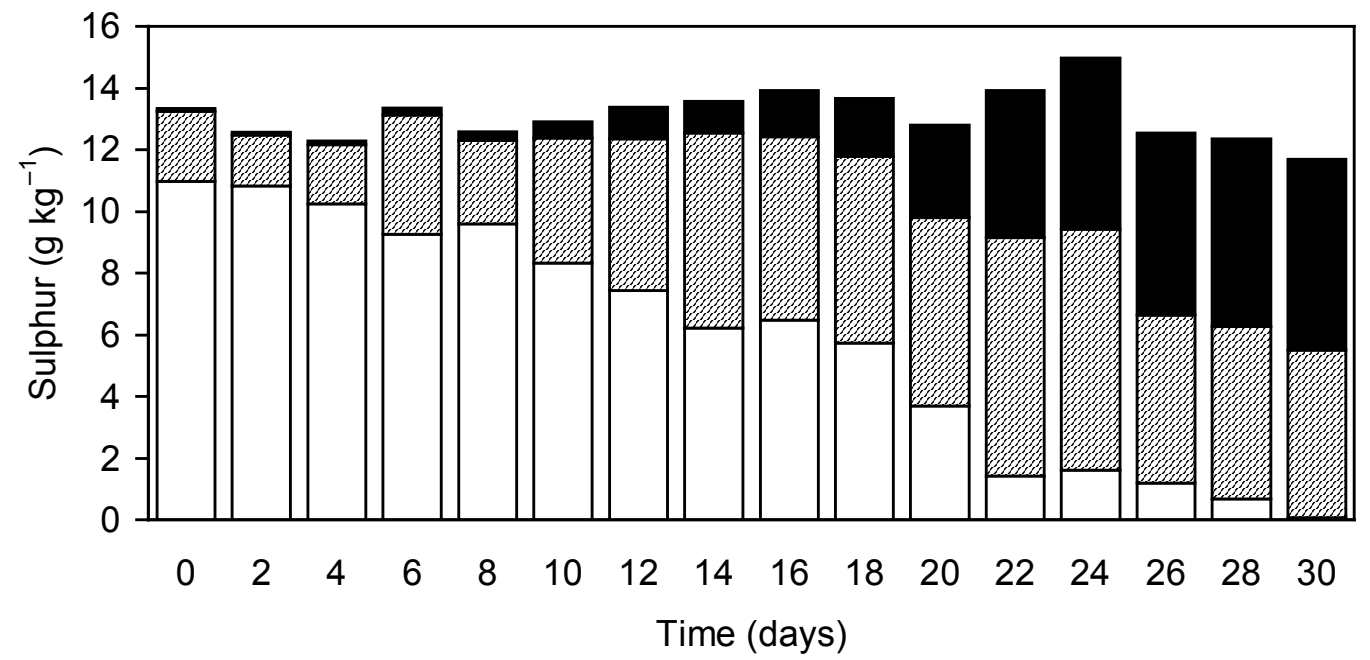

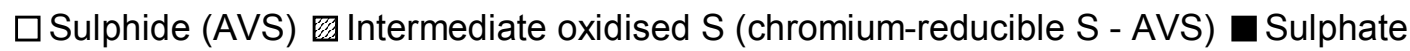

Figure 1. Sum of chromium-reducible sulphur and sulphate sulphur as a function of time. Sulphide forms were plotted as a fraction of chromium-reducible sulphur. 